\title{
AUDIOLOGICAL FINDINGS AND AIDED PERFORMANCE IN INDIVIDUALS WITH AUDITORY NEUROPATHY SPECTRUM DISORDER (ANSD) - A RETROSPECTIVE STUDY
}

\author{
Jijo P.M., Asha Yathiraj
}

Department of Audiology, All India Institute of Speech and Hearing, Mysore, Karnataka, India

Corresponding author: Jijo P.M., Lecturer in Audiology, Department of Audiology, All India Institute of Speech and Hearing, Mysore, Karnataka, India, Phone: +91 9620467904, e-mail: jijoaudio@gmail.com

\begin{abstract}
Background: There is controversy in the literature regarding the utility of amplification in individuals with auditory neuropathy spectrum disorder (ANSD). Most of the studies regarding the effect of amplification on speech perception in ANSD have been carried out on children. Only a few investigations have studied this aspect in late onset ANSD. The majority of these studies report no aided improvement, with only a few reporting minimal benefit. Further, none of the studies in late onset ANSD evaluated the relation between audiological test results and aided improvement.
\end{abstract}

Aim: The study aimed to investigate the effect of amplification on speech identification scores (SISs) in individuals with late onset ANSD. It also determined a relation between audiological test results and aided improvement.

Method: The retrospective study was carried out by reviewing the clinical records of 64 patients with late onset ANSD.

Results: Improvement in speech identification with hearing aids was observed in $30 \%$ of the ears evaluated. Correlation analysis revealed that there was a significant positive correlation between SISs obtained under headphones and aided performance. However, no relation was found between the degree of hearing loss and the aided performance or on the unaided sound field SIS.

Conclusion: Unlike earlier studies, it was found that individuals with late onset ANSD did show improvement in speech perception when using hearing aids. The SIS under headphones was a major indicator of aided performance in adults with late onset ANSD.

Key words: auditory neuropathy spectrum disorder (ANSD) • hearing aids • speech identification score (SIS) • peripheral neuropathy

\section{CONCLUSIONES AUDIOLÓGICAS Y RESULTADOS CON AUDÍFONOS \\ EN LOS TRASTORNOS DEL ESPECTRO DE NEUROPATÍA AUDITIVA: ESTUDIO RETROSPECTIVO}

\section{Resumen}

Introducción: En las publicaciones sobre el tema la amplificación de sonidos mediante audífonos en las personas con trastornos del espectro de neuropatía auditiva (ANSD) despierta controversia. La mayoría de estudios sobre la influencia de la amplificación de sonidos en la percepción del habla en los ANSD se realizaron con niños. Hay pocos trabajos que hayan analizado este aspecto en la fase avanzada de los ANSD. La mayoría de estos estudios demostró la ausencia de beneficios del uso de audífonos, solo en unos pocos se describieron beneficios mínimos. Es más, en ninguno de los trabajos sobre la fase avanzada de los ANSD se estudió la dependencia entre los resultados de las pruebas de audición y los beneficios de la amplificación.

Objetivo: El trabajo tiene como objetivo estudiar los efectos de la amplificación de sonidos sobre los resultados de reconocimiento del habla (SIS) en las personas en fase avanzada de ANSD. También analiza la dependencia entre los resultados de las pruebas de audición y los beneficios de la amplificación.

Método: Estudio retrospectivo realizado mediante el análisis de la documentación médica de 64 pacientes en fase avanzada de ANSD.

Resultados: Se observó una mejora de los resultados de identificación del habla con audífonos en el 30\% de los oídos estudiados. El análisis de la correlación demostró que existe una correlación positiva importante entre los resultados de los SIS 
obtenidos con auriculares y los resultados con audífonos. Sin embargo, no se encontró ninguna relación entre el grado de hipoacusia y los resultados con audífonos o los resultados de los SIS no asistidos en un campo acústico libre.

Conclusión: A diferencia de otros estudios se estableció que, en la fase avanzada de los ANSD, se produce una mejora de la percepción del habla cuando se utilizan audífonos. Los resultados de los SIS con auriculares fueron un índice importante de los resultados después de utilizar la amplificación en pacientes adultos en fase avanzada de ANSD.

Palabras clave: trastornos del espectro de neuropatía auditiva (ANSD) • audífonos • resultados de reconocimiento del habla (SIS) • neuropatía periférica

\section{АУДИОЛОГИЧЕСКОЕ ЗАКЛЮЧЕНИЕ И РЕЗУЛЬТАТЫ В СЛУХОВЫХ АППАРАТАХ В НАРУШЕНИЯХ СПЕКТРА СЛУХОВОЙ НЕВРОПАТИИ: РЕТРОСПЕКТИВНОЕ ИССЛЕДОВАНИЕ}

\section{Изложение}

Введение: В литературе предмета полезность применения усиления звуков с помощью слуховых аппаратов у людей с нарушениями спектра слуховой невропатии (ANSD) пробуждает контроверсии. Большинство исследований на тему влияния усиления звуков на перцепцию речи при ANSD проводилось у детей. Только некоторые работы анализировали этот аспект на поздней стадии ANSD. Большинство этих исследований сообщало об отсутствии пользы применения слуховых аппаратов, только в некоторых описана минимальная польза. Более того, ни в одной работе на тему поздней стадии ANSD не исследована зависимость между результатами аудиологических тестов и пользой усиления.

Цель: целью работы является исследование эффектов влияния усиления звуков на результаты восприятия речи (SIS) у людей на поздней стадии ANSD. Она анализирует также зависимость между результатами аудиологических тестов и пользой усиления.

Метод: ретроспективное исследование, проведенное путем анализа медицинской документации 64 пациентов на поздней стадии ANSD.

Результаты: Улучшение результатов идентификации речи в слуховых аппаратах наблюдалось в 30\% исследованых ушей. Анализ взаимозависимости показал, что существует значительная положительная зависимость между результатами SIS, получеными в наушниках и результатами в слуховых аппаратах. Однако, взаимосвязь между степенью тугоухости и результатами в слуховых аппаратах или результатами неуправляемых SIS в свободном звуковом поле не найдена.

Заключение: в отличие от других исследований, определено, что на поздней стадии ANSD наступает улучшение перцепции речи во время использования слуховых аппаратов. Результаты SIS в наушниках были важным показателем результатов после применения усиления у взрослых пациентов на поздней стадии SIS.

Ключевые слова: нарушения спектра слуховой невропатии (ANSD) • аппараты • результаты восприятия речи (SIS), периферическая невропатия

\section{WYNIKI AUDIOLOGICZNE I KORZYSCI Z APARATÓW SŁUCHOWYCH U OSÓB Z ZABURZENIAMI SPEKTRUM NEUROPATII SŁUCHOWEJ: BADANIE RETROSPEKTYWNE}

\section{Streszczenie}

Wprowadzenie: W literaturze przedmiotu użyteczność zastosowania wzmocnienia dźwięków za pomocą aparatów słuchowych u osób z zaburzeniami spektrum neuropatii słuchowej (ANSD) budzi kontrowersje. Większość badań na temat wpływu wzmocnienia dźwięków na percepcję mowy w ANSD była prowadzona na dzieciach. Jedynie nieliczne prace analizowały ten aspekt w późnej postaci ANSD. Większość tych badań donosiła o braku korzyści z zastosowania aparatów słuchowych, tylko w kilku opisano minimalne korzyści. Co więcej, w żadnej z prac na temat późnej postaci ANSD nie została zbadana zależność między wynikami testów audiologicznych a korzyścią ze wzmocnienia. 
Cel: Praca ma na celu zbadanie efektów wzmocnienia dźwięków na wyniki rozpoznawania mowy (SIS) u osób z późną postacią ANSD. Analizuje także zależność pomiędzy wynikami testów audiologicznych a korzyścią ze wzmocnienia.

Metoda: Badanie retrospektywne przeprowadzone w drodze analizy dokumentacji medycznej 64 pacjentów z późną postacią ANSD.

Wyniki: Poprawa wyników identyfikacji mowy w aparatach słuchowych została zaobserwowana w 30\% badanych uszu. Analiza korelacji wykazała, że istnieje istotna pozytywna korelacja pomiędzy wynikami SIS uzyskanymi w słuchawkach a wynikami $\mathrm{w}$ aparatach słuchowych. Jednak nie znaleziono relacji pomiędzy stopniem niedosłuchu a wynikami w aparatach słuchowych lub wynikami niewspomaganych SIS w swobodnym polu dźwiękowym.

Wniosek: W odróżnieniu od innych badań ustalono, że w późnej postaci ANSD występuje poprawa percepcji mowy podczas stosowania aparatów słuchowych. Wyniki SIS w słuchawkach były ważnym wskaźnikiem wyników po zastosowaniu wzmocnienia w dorosłych pacjentów z późną postacią ANSD.

Słowa kluczowe: zaburzenia spektrum neuropatii słuchowej (ANSD) • aparaty słuchowe • wyniki rozpoznawania mowy (SIS) - neuropatia obwodowa

\section{Background}

From the time auditory neuropathy spectrum disorder (ANSD) was discovered, researchers have explored its audiological characteristics and management [1]. The term ANSD is used in line with a recommendation by a clinical review panel at the Consensus Conference on Auditory Neuropathy/Dyssynchrony, Como, Italy, in June 2008. Diversity in patients' auditory perceptual ability and lesion site have led to difficulties in clinical management. Hearing aids as a rehabilitation option in individuals with ANSD have been criticized since they are designed to compensate for the loss of outer hair cells rather than temporal dyssynchrony resulting from neural dysfunction [2].

Studies concerning the effect of hearing aids on outer hair cell function have shown variable results. Although a few studies have reported outer hair cell disruption in children using high-gain hearing aids $[3,4]$, there are other reports of normal outer hair cell function even after longterm hearing aid use [4-7]. Furthermore, the presence or absence of otoacoustic emissions as an indicator of outer hair cell integrity has not been found to be related to hearing thresholds or speech perception abilities [6-8]. Despite contradictions regarding the utility of hearing aids for individuals with ANSD, several studies have reported benefits from hearing aids in a few cases that involved elevated thresholds $[6,8,9-13]$, leading to recommendations that ANSD patients should be fitted with hearing aids.

The above literature on amplification benefit has predominantly been carried out on paediatric populations [9-13]. These studies have clearly shown that hearing aids resulted in development of speech and language abilities in children who were in their pre-verbal stage. This aided benefit has been attributed to the early diagnosis and management during the critical period of speech and language development [6-8]. It has also been suggested that children who benefitted from amplification might have pathology similar to that of sensorineural hearing loss, resulting in similar perceptual abilities and aided performance $[12,13]$.

Amplification benefit, reported in individuals with late onset ANSD, has been noted in only a limited number of studies. Vanaja and Manjula [14] reported that use of hearing aids resulted in improvement in speech perception in 3 out of 5 young adults with ANSD. This improvement was observed only in cases with a late latency response, which was considered to be an indicator of better synchrony at the level of auditory cortex and this perhaps compensated for brainstem dyssynchrony. Similarly, Zeng and Liu [15] reported aided improvement in speech perception in 7 out of 9 adults with late onset ANSD. It was reported that binaural acoustic stimulation was significantly better than monaural acoustic stimulation using both clear and conversational speech. However, the extent of aided improvement is questionable as there was no comparison between unaided and aided performance.

Shallop [16], Sininger et al. [17], and Widen et al. [18] reported lack of aided improvement in individuals with late inset ANSD. However, these studies were carried out with small groups each having less than 5 participants, underlining how the utility of hearing aids needs to be established on a larger sample size. Starr et al. [1] carried out a study on a larger sample of 10 subjects noted that 8 had associated peripheral neuropathy and all patients had progressive hearing impairment that probably resulted from the neuropathic condition. The progressive nature of late onset ANSD has also been noted to result in poor aided performance in adults [16-18]. The above literature shows that those with post-verbal ANSD have limited improvement in speech perception using hearing aids.

Although late onset ANSD is commonly reported to be associated with peripheral neuropathy $[1,19]$, there are reports of ANSD without any associated neuropathic condition $[20,21]$. In those with associated peripheral neuropathy, demyelination of neurons or axonal neuropathy have been suggested to be the cause. However, the pathophysiology in those without associated peripheral neuropathy is not clearly understood. Shivashankar et al. [21] reported no deterioration in hearing thresholds over time in 24 cases with late onset ANSD. They opined that the lack of any associated neuropathic problems might explain why the thresholds did not progress. However, none of the above studies have analysed the aided performance in their patients [20,21]. Vanaja and Manjula [14] reported aided improvement in 5 cases who had no associated peripheral neuropathy. Similarly, Zeng and Liu [15] reported that 
among the 7 cases who showed aided improvement, only 1 had associated peripheral neuropathy. Hence, there is a need to study whether aided performance differs in an adult population with ANSD which does not suffer associated peripheral neuropathy or progressive hearing loss.

Only a few studies have been done to find the relation between audiological test results and aided performance in individuals with ANSD. Rance et al. [12] reported that aided performance in children with ANSD correlated with the presence of cortical potentials. Similar findings have been noted in a few adults with ANSD [14]. Among children with ANSD, audiological test results, such as degree of hearing loss and unaided SIS, were not found to predict aided performance [6]. However, this has not been investigated in adults with ANSD. Such an investigation may offer a means of predicting hearing aid benefit based on audiological test results.

Hence, the aim of the study was to investigate aided performance in a large group of adults with ANSD, the majority of whom did not have any symptoms of peripheral neuropathy or progressive hearing loss. In addition, the relation between audiological test findings (PTA, SIS under headphones, and SIS in a sound-field) and aided performance were also investigated.

\section{Methods}

\section{Participants}

In this register-based study, the clinical records of patients who visited the Department of Audiology, All India Institute of Speech and Hearing, Mysore, between October 2008 and October 2010 were reviewed. The study was carried out adhering to the guidelines of the institute ethics committee. A total of 120 cases with ANSD were identified using the diagnostic criteria given by Starr et al. [7] and Berlin et al. [22]. Among the 120 cases, 64 with late onset ANSD, who had undergone aided speech identification testing were selected for the study. Exactly 56 cases were excluded since 18 of them were below 3 years of age and standard speech identification testing could not be carried out on them, 31 cases had either normal hearing sensitivity or minimal hearing loss bilaterally, 5 patients had congenital onset of ANSD, and 2 were fitted with cochlear implants.

All 64 participants with late onset ANSD reported normal hearing and speech perception abilities until the first or second decade of life and then a sudden onset of the condition. The etiological factors and audiological characteristics of these participants have been described in an earlier publication [23]. Among the 64 selected cases, 40 had bilateral symmetrical hearing loss (difference in pure-tone average between the two ears $<10 \mathrm{~dB} \mathrm{HL}$ ), 22 had asymmetrical hearing loss, and the remaining 2 had unilateral ANSD. Aided speech identification testing was carried out separately in each ear of the 40 cases that had bilateral hearing loss. In the 22 cases with asymmetrical hearing loss, only the poorer ear was tested while the better ear was blocked. This was done to prevent the participation of the better ear which had either normal hearing sensitivity or minimal hearing loss. In those with unilateral
Table 1. Audiological details of the participants.

\begin{tabular}{|c|c|c|}
\hline & Number & Percentage \\
\hline \multicolumn{3}{|l|}{ Gender* } \\
\hline Male & 24 & 37.5 \\
\hline Female & 40 & 62.5 \\
\hline \multicolumn{3}{|c|}{ Degree of hearing loss ${ }^{* *}$} \\
\hline Mild & 15 & 14.4 \\
\hline Moderate & 41 & 39.4 \\
\hline Moderately severe & 21 & 20.2 \\
\hline Severe & 9 & 8.7 \\
\hline Profound & 18 & 17.3 \\
\hline \multicolumn{3}{|c|}{$\begin{array}{l}\text { Bilateral/unilateral hearing } \\
\text { loss* }\end{array}$} \\
\hline Bilateral & 62 & 96.8 \\
\hline Unilateral & 2 & 3.2 \\
\hline \multicolumn{3}{|c|}{ Symmetrical/asymmetrical* } \\
\hline Symmetrical & 40 & 62.5 \\
\hline Asymmetrical & 24 & 37.5 \\
\hline \multicolumn{3}{|l|}{ Otoacoustic emissions* } \\
\hline Present & 64 & 100.0 \\
\hline Absent & None & \\
\hline \multicolumn{3}{|c|}{$\begin{array}{l}\text { Auditory brainstem response/ } \\
\text { acoustic reflex* }\end{array}$} \\
\hline Present & None & \\
\hline Absent & 64 & 100.0 \\
\hline
\end{tabular}

* Number of cases; ${ }^{* *}$ number of ears.

ANSD, only the affected ear was tested while the normal ear was blocked. Thus, a total of 104 ears were evaluated using hearing aids. Aided audiograms were established in those with very poor aided SIS, to confirm that their aided thresholds were within the speech spectrum.

The demographic and audiological findings of the participants are given in Table 1 . The age of the participants ranged from 11 to 45 years with a mean age of $23.7 \pm 9.2$ years. Their hearing loss ranged from mild to profound, and SIS under headphones ranged from 0 to $56 \%$ with a mean score of $9.8 \pm 4.2$. Additionally, there was no correlation between degree of hearing loss and SIS under headphones $(r=-0.45, p<0.01)$. This is shown in Figure 1. Further, the means and confidence intervals of the pure-tone average and SIS under headphones are given in Figure 2. All patients had an 'A' type tympanogram and absence of acoustic reflexes bilaterally. Transient evoked otoacoustic emissions (TEOAEs) were present in all participants. None had auditory brainstem responses (ABRs) in either ear. Otological examination revealed that all cases had normal middle ear function. Neurological examination indicated that most had no signs and symptoms of any peripheral neuropathy or space occupying lesion. Only 4 cases had symptoms of spinocerebellar ataxia. All cases had no earlier experience with the use of hearing aids.

\section{Procedure}

\section{Audiological evaluation}

All investigations were carried out in a sound treated tworoom set-up that met ANSI specifications [24]. Pure-tone thresholds were obtained via the modified Hughson and Westlake procedure using calibrated audiometers (Madsen-Orbiter OB-922 or GSI-61). Calibrated immittance 


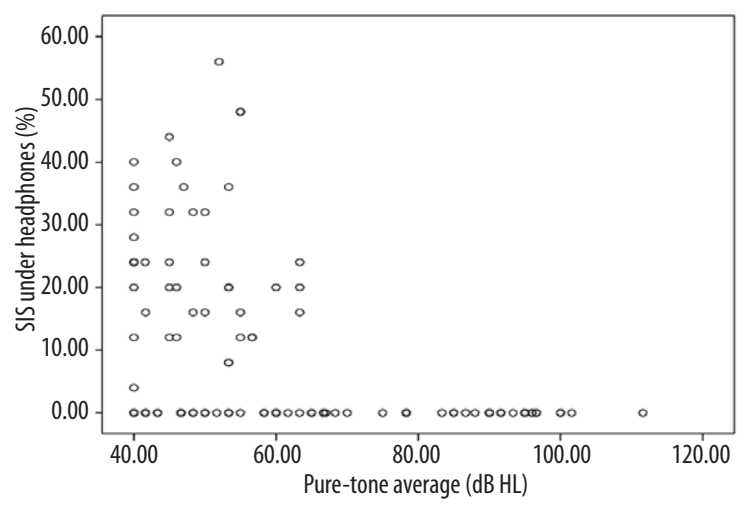

Figure 1. Relation between pure-tone average and SIS obtained under headphones. There is no significant correlation. Although higher SIS was found in those with PTA less than $60 \mathrm{~dB} \mathrm{HL}$, many patients with similar loss had no measurable SIS.

instruments (GSI-33 or GSI-Tympstar) were used to obtain tympanograms and acoustic reflex thresholds. SIS was obtained using a phonemically balanced Kannada word test developed by Yathiraj and Vijayalakshmi [25]. This was done under headphones where each ear of a patient was tested independently at $40 \mathrm{~dB}$ HL above their speech recognition threshold. Any two of the four equivalent lists of the test that contained 25 words in each list was used. TEOAEs were recorded using an Otodynamics ILO 292 or Madsen Capella 1.3. Non-linear clicks were presented at $80 \mathrm{~dB}$ peak SPL. Responses having a signal-to-noise ratio of more than $6 \mathrm{~dB}$ and reproducibility above $80 \%$ were considered as responses indicating the presence of normal functioning outer hair cells. ABR was recorded using a two-channel auditory evoked potential (AEP) system (Biologic Navigator version 7.0.0 or Intelligent Hearing Systems Smart EP version 2.12C). Click stimuli were presented at $90 \mathrm{~dB} \mathrm{nHL}$ at a repetition rate of $11.1 / \mathrm{sec}$.

\section{Hearing aid evaluations}

The hearing aid trial was carried out using a routine procedure followed at the Department of Audiology. The patients were tested with either digital behind-the-ear (BTE) hearing aids or analog body-level hearing aids, depending on their income. The cases who opted for digital hearing aids were tested with a minimum of three different devices, while those who chose body-level hearing aids were tested with at least two different types. To ensure that the electro-acoustic characteristics of the hearing aids met the manufacturer's specifications, the devices were assessed in a hearing aid test box (Fonix 7000). The digital hearing aids were programmed using a personal computer, integrated with a HiPro interface, in which NOAH and the specific hearing aid's software were installed. The hearing aid was programmed according to the first fit generated from the NAL-NL1 formula. In case of analog body-level hearing aids, the gain of the instrument that matched the degree of hearing loss was chosen.

Initially, unaided performance was obtained for each participant using the phonemically balanced word test in

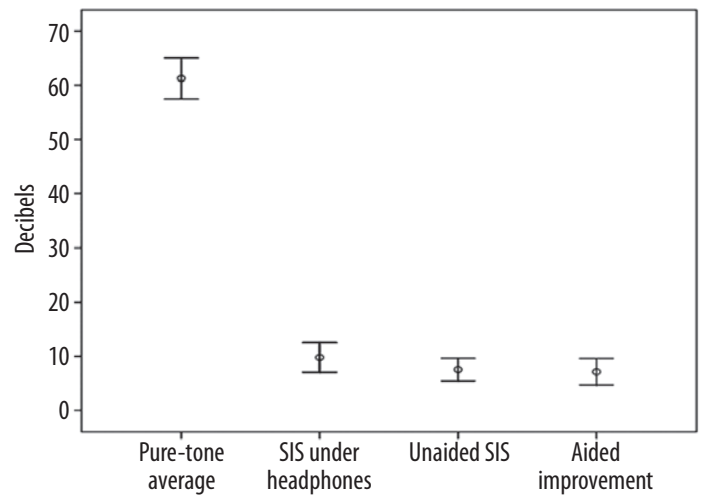

Figure 2. Means and 95\% confidence intervals of PTA, SIS under headphones, unaided SIS, and aided improvement.

Kannada [25]. Stimuli were presented at $40 \mathrm{~dB}$ HL through a loudspeaker placed at $0^{\circ}$ azimuth. The aided performance was obtained using a procedure similar to that of the unaided evaluation. Aided testing was done separately in each ear using each hearing aid. Soon after testing, each patient was given some time to use their hearing aids outside the test room. This was done to check the patient's preference among the three hearing aids that were tried. Finally, the device that resulted in the highest speech identification score as well as being preferred by the patient was prescribed. The scores obtained from this particular hearing aid were analyzed. Hearing aids were also recommended for a few patients who had severe to profound hearing loss along with low SIS. This was done to help in auditory awareness rather than speech understanding. Cases that showed no aided improvement were counselled regarding the use of communication strategies as well as the possible utility of cochlear implants. The hearing aid trial lasted 20-30 minutes, including determining speech perception and the patient's preference.

\section{Results}

\section{Aided improvement}

The difference between aided and unaided performance revealed that hearing aids gave improved speech perception in 39 of the 104 ears having late onset ANSD. However, the 5 children with congenital ANSD did not show any improvement with hearing aids. In those with late onset ANSD, the aided improvement ranged from $4 \%$ to $52 \%$, with a mean score of $19.1 \pm 14.0 \%$. The aided SIS in the remaining 65 ears did not show improvement. For further analysis, the cases with late onset ANSD were divided into two groups. Group I, with a better SIS, consisted of 31 ears that had an improvement greater than -1 SD of the mean score. Group II, with a poorer SIS, consisted of 73 ears with an aided improvement that was less than $-1 \mathrm{SD}$ of the mean.

It can be observed in Figure 3 that, among the 31 ears in Group I, 16 (51.6\%) were tested with BTE hearing aids and the remaining 15 (48.4\%) with body-level hearing aids. However, in Group II, out of 73 ears, 55 (75.3\%) were tested using body-level hearing aids and the remaining 18 


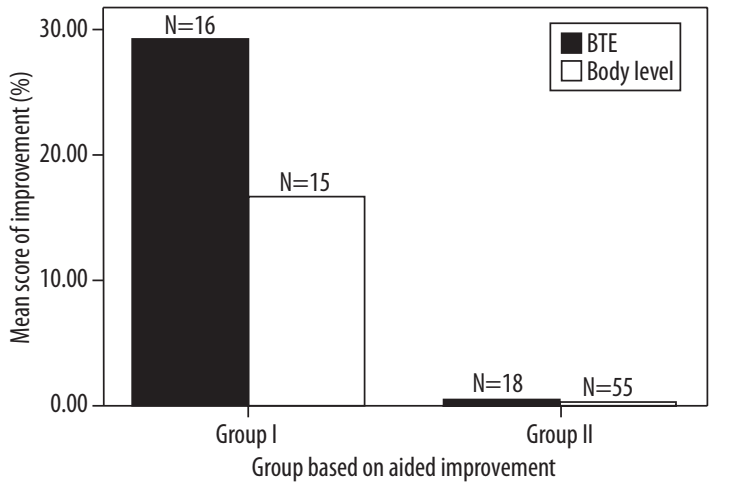

Figure 3. Mean score of aided improvement in Group I and Group II using body-level or BTE hearing aids. Aided improvement was significantly better using BTE hearing aids compared to that of body level aids in Group I. No such difference was found between BTE and body-level aids in Group II.

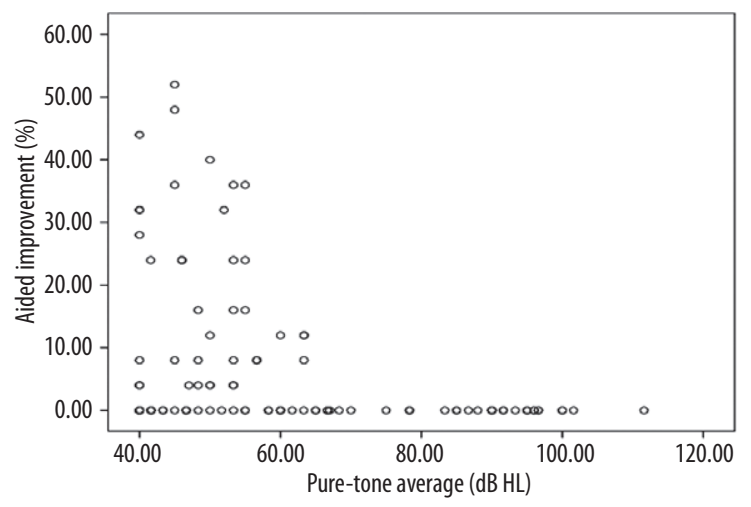

Figure 4. Relation between pure-tone average and aided performance in 104 ears with ANSD. All the patients who improved using hearing aids had hearing loss less than $60 \mathrm{~dB}$. HL. The results obtained from many patients who had $0 \%$ aided improvement overlap.

(24.7\%) with BTE hearing aids. It was also noticed that in Group I, those using BTE hearing aids, the device resulted in a mean improvement of $29 \%( \pm 13.6 \%)$ while in those using body level hearing aids, it improved only by $16.5 \%( \pm 9.3 \%)$. In order to compare the aided performance across BTE and body-level hearing aids, an independent sample $t$-test was performed. It was found that there was a significant difference between the performance with the two styles of hearing aids $(t=2.96, p<0.05)$. However, no significant difference in performance was found between the two styles of hearing aids in Group II $(t=0.23, p>0.05)$.

Relation between audiological findings and aided improvement

\section{Degree of hearing loss and aided performance}

The relation between degree of hearing loss of the 104 ears and their aided improvement was analyzed. There was

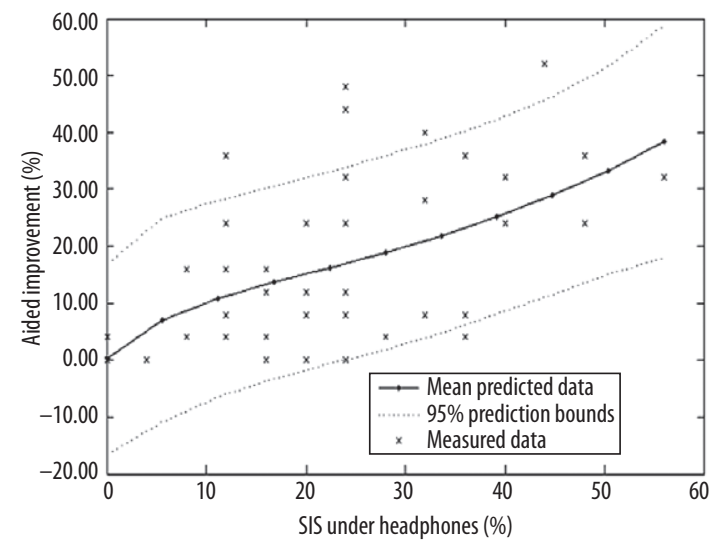

Figure 5. Relation between SIS under headphones and aided performance in 104 ears with ANSD. Also shown is the non-linear regression (Eq. 1).

a significant but weak negative correlation between the two variables $(r=-0.38, p<0.01)$. It can be observed from Figure 4 that those who showed improvement using hearing aids had PTA less than $60 \mathrm{~dB}$ HL. However, a large number of cases who showed no improvement using hearing aids also had PTAs less than $60 \mathrm{~dB}$ HL. In contrast to those with the lesser degree, it was evident that none of the cases who had severe-to-profound hearing loss showed improvement using hearing aids.

\section{SIS under headphones and aided performance}

The relation between SIS under headphones and aided performance was also investigated using Pearson's product moment correlation. It was found that there was a significant positive correlation between the two variables $(r=0.75$, $p<0.01)$. From Figure 5 it can be observed that cases that had greater than $40 \%$ SIS under headphones had higher aided improvement ranging from $24 \%$ to $52 \%$. Unlike these individuals, those who had lower SIS under headphones (10-40\%) had limited aided improvement or did not improve. Cases that had 0\% SIS under headphones showed no improvement with hearing aids.

As there was a significant correlation between the SIS obtained under headphones and the aided improvement, a nonlinear regression analysis was performed. This was done to enable the prediction of the dependent variable (aided improvement) from the independent variable (SIS under headphones). Figure 5 shows the regression line with $95 \%$ confidence interval and Equation (1) gives the regression equation for the prediction. It can also be noted that except for 6 outliers, all patients fell within the $95 \%$ confidence interval. Hence, the regression equation clearly predicts the aided improvement from SIS obtained under headphones.

$$
y=a\left(e^{b x}\right)+c\left(e^{d x}\right)
$$

In Equation (1), $y$ is the predicted aided improvement, $x$ is the SIS under headphones, and $a, b, c$, and $d$ are constants where $a=-9.2, b=-0.1544, c=9.38$, and $d=0.02516$ ). The $r^{2}$ value of the model was 0.57 with a standard error estimate of 8.34 . 


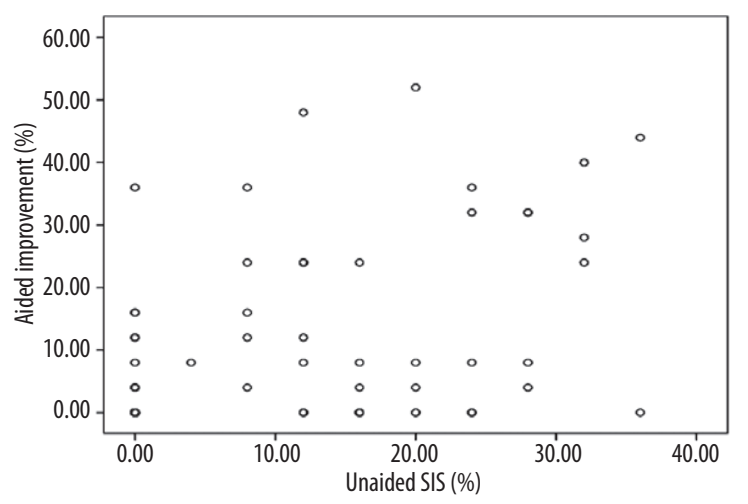

Figure 6. Relation between unaided sound field SIS and aided performance in 104 ears with ANSD. There is no relation between unaided sound field SIS and aided improvement. Results from many patients who had $0 \%$ aided improvement overlap.

\section{SIS (sound field) and aided performance}

Pearson's product moment correlation revealed that there was a weak positive, though significant, correlation between the unaided sound field SIS and the aided improvement $(r=0.52, p<0.01)$. The lack of correlation between the unaided sound field SIS and the aided performance can be observed in Figure 6.

\section{Discussion}

\section{Aided improvement}

The results of the present study revealed that a large number of cases $(70 \%)$ did not show improvement in speech perception with the use of hearing aids. However, amplification resulted in an improvement in a small group (30\%) of individuals with ANSD. Additionally, speech perception of the 5 children who had congenital ANSD did not show any improvement with amplification. Hence, the speech perception improvement found in a few post-verbal ANSD patients does not necessarily imply that a hearing aid would help in learning of speech and language at a pre-verbal stage.

Aided speech perception improvement in late onset ANSD is in contrast with earlier reports where adults often did not benefit from hearing aids [1,16-18]. The variation in findings could be attributed to the presence of associated neuropathy and the progressive nature of the condition. Starr et al. [1] reported that $80 \%(8 / 10)$ of their patients had associated peripheral neuropathy and the remaining $20 \%$ were considered not to show signs of peripheral neuropathy due to the early stage of the condition. They observed that hearing loss progressed gradually and none of their patients improved with amplification. Shallop [16] and Widen et al. [18] described two cases, each with late onset ANSD and rapid deterioration in hearing abilities. They reported that the progressive nature of the disorder might have resulted in poor aided performance in these individuals.
Unlike the earlier reported studies [1,16-18], the cases in the present study did not have any associated neuropathic conditions. Additionally, the majority of them reported stable hearing thresholds and speech perception over a period of time. Hence, it can be construed that the nonprogressive nature of hearing abilities in these cases might have resulted in the aided speech perception improvement. Shivashankar et al. [21] linked the absence of any associated neurological condition with the presence of stable hearing thresholds. Analogous to the findings of the present study, Vanaja and Manjula [14] reported aided improvement in speech perception in 3 of the 5 adults with ANSD they studied. None of them had any history of associated neurological problems. Similarly, Zeng and Liu [15] reported that among the 7 patients who showed clear speech advantage with conversational speech, only 1 had associated peripheral neuropathy. Although a small number of individuals did show aided improvement in speech perception in the current study, a large number of them did not improve with the use of hearing aids. Additionally, in the latter group the majority (60/64) did not have any signs of associated peripheral neuropathy. Hence, it can be concluded that factors other than peripheral neuropathy might influence the aided improvement in individuals with ANSD.

Relation between audiological test results and aided improvement

The correlation analysis was done to determine the other possible variables that influence aided speech perception. It was found that there was a significant high positive correlation between SIS under headphones and the aided improvement. Additionally, the regression analysis showed that aided improvement could be predicted from the SIS obtained under headphones (at $40 \mathrm{~dB}$ SL ref to SRT). However, on account of the variability found in the aided improvement as shown in Figure 5, it can be construed that SIS under headphones may be used as an indicator of aided improvement in adults with ANSD, though not always. Cone-Wesson et al. [10] suggested that performance - intensity (PI) function in individuals with ANSD might be a sign of suprathreshold processing and aided performance. Hence, the SIS under headphones obtained at a level of 40 dB HL above SRT might be an indicator of suprathreshold processing in these individuals. The findings of Deltenre et al. [8] on a 6-year-old child with ANSD substantiate that unaided performance at a higher presentation level $(70 \mathrm{~dB})$ when compared to a lower presentation level $(55 \mathrm{~dB})$ was a good indicator of low-level aided performance. At the higher presentation level, the child's performance was almost equal to that in the low-level aided condition. Thus, it can be concluded that patients who obtained higher SIS at suprathreshold levels would show improvement using hearing aids. In contrast, those who scored poorly might have poor perceptual abilities at higher levels leading to poor aided performance. Thus, it can be concluded that obtaining a PI function in individuals with ANSD might give better understanding of their suprathreshold processing and aided performance. Poor SIS in these patients at higher presentation levels might result from poor neural synchrony. Young and Sachs [26] showed that at higher presentation levels the neural firing rate saturates and fails to preserve spectral peaks. However, normal individuals 
can discriminate vowels even at higher presentation levels even though the spectral peaks are distorted. They opined that a combination of neural firing rate and neural synchrony (measured as 'averaged localized synchronized rate') might have preserved vowel identity even at higher levels. Hence, individuals with ANSD who have poor neural synchrony would have to depend on spectral cues for speech perception. However, since at higher presentation levels spectral cues are distorted, individuals with ANSD would have difficulty in speech perception at these levels. In contrast, cases that perform better at higher levels might have relatively well preserved neural synchrony to compensate for the distorted spectral cues.

The correlation analysis showed that there was no relation between degree of hearing loss and aided performance. The lack of correlation between degree of hearing loss and aided performance could have been on account of the high variability in performance obtained from individuals who had mild to moderate hearing loss. Furthermore, it was observed that all patients who improved with hearing aids had mild to moderate hearing loss, whereas none with severe to profound hearing loss showed any improvement. Lack of aided improvement in adults with severe to profound degrees of hearing loss might be due to the greater impact of dyssynchrony. In contrast, patients who had mild to moderate hearing loss, and some amount of speech perception, might have better neural synchrony compared to individuals with severe hearing loss. Thus, the present study reveals that degree of hearing loss alone does not decide the aided performance in those with mild to moderate ANSD. This is in contrast to reports of patients with sensorineural hearing loss, where generally those with mild-to-moderate hearing loss improve maximally using hearing aids $[27,28]$. In contrast, in cases with ANSD, aided improvement is found only in those patients having both mild/moderate hearing loss along with SIS above $40 \%$.

It was noted that there was no relation between the unaided sound-field SIS and aided improvement in adults with ANSD. This could be because unaided sound field SIS was obtained at a lower level ( $40 \mathrm{~dB} \mathrm{HL}$ ) and did not give any information on suprathreshold processing, the factor that is suggested to be an indicator of aided improvement [10]. Similarly, Rance et al. [6] reported that unaided SIS is not a predictive factor in children with ANSD.

Further, among the patients who had shown improvement in speech perception (Group I), aided improvement was significantly better in those who were tested using digital BTE hearing aids compared to those with analog bodylevel hearing aids. The clearer sound quality obtained in digital devices might have given better speech perception. It is also possible that analog hearing aids were unable to provide frequency-specific gain for many patients who had sloping or peaked audiometric configurations. However, no such difference in performance was observed with analog and digital hearing aids in Group II, as none of them benefitted from any device. Thus, it is evident that in individuals who do not benefit from hearing aids, the signal processing strategy (analog/digital) did not influence speech perception performance.

\section{Conclusions}

The present study has shown that hearing aids might provide improved speech identification even in adults who have late onset ANSD. This finding is in contrast to earlier reports in which adults usually did not benefit from hearing aids. These diverging findings could be due to the lack of associated neuropathy and non-progressive nature of ANSD in our patients. However, factors other than peripheral neuropathy might influence the aided improvement in individuals with ANSD since several cases also did not show aided improvement. Additionally, it was found that patients who had higher SIS under headphones showed higher aided improvement than those who had poor SIS under headphones. This suggests that the SIS under headphones obtained at a high presentation level might be a good indicator of suprathreshold processing and aided improvement. However, to draw a definite conclusion, experimental studies investigating the relation between the performance-intensity function and aided performance need to be carried out. As aided evaluations are done in a sound field, the performance - intensity function also has to be obtained in a sound field rather than under headphones. Additionally, speech perception scores in noise could provide information about how those ANSD cases who have adequate speech identification scores in quiet might perform in noisy situations.

\section{Acknowledgement}

We express our sincere thanks to the audiologists in the Department of Audiology who evaluated our patients.

\section{References:}

1 Starr A, Picton TW, Sininger YS, Hood LJ, Berlin CI. Auditory neuropathy. Brain, 1996; 119: 741-53.

2 Berlin CI, Hood LJ, Hurley A, Wen H. Hearing aids: Only for hearing impaired patients with abnormal otoacoustic emissions. In: Berlin CI, (Ed.), Hair Cells and Hearing Aids. Singular Publishing Group, 1996; 99-112.

3 Trautwein PG, Sininger YS, Nelson R. Cochlear implantation of auditory neuropathy. J Am Acad Audiol, 2000; 11: 309-15.

4 Sininger Y, Oba S. Patients with auditory neuropathy: who are they and what can they hear? In: Sininger YS, Starr A, (eds.), Auditory Neuropathy: A New Perspective on Hearing Disorders. San Diego: Singular-Thomson Learning, 2001; 15-35.

5 Katona G, Buki B, Farkas Z, Pytel J, Simon-Nagy E, Hirschberg J. Transitory evoked otoacoustic emission (TEOAE) in a child with profound hearing loss. Int J Pediatr Otorhinolaryngol, 1993; 26: 263-67.

6 Rance G, Beer DE, Cone-Wesson B et al. Clinical findings for a group of infants and young children with auditory neuropathy. Ear Hear, 1999; 20: 238-52.

7 Starr A, Sininger YS, Pratt $\mathrm{H}$. The varieties of auditory neuropathy. J Basic Clin Physiol Pharmacol, 2000; 11: 215-30.

8 Deltenre P, Mansbach AL, Bozet C et al. Auditory neuropathy with preserved cochlear microphonics and secondary loss of otoacoustic emissions. Audiology, 1999; 38: 187-95.

9 Berlin CI, Hood LJ, Morlet T et al. Multi-site diagnosis and management of 260 patients with auditory neuropathy/dyssynchrony (auditory neuropathy spectrum disorder). Int J Audiol, 2010; 49: 30-43. 
10 Cone-Wesson B, Rance G, Sininger YS. Amplification and rehabilitation strategy for patients with auditory neuropathy. In: Sininger YS, Starr A (eds.), Auditory Neuropathy: A New Perspective on Hearing Disorders. San Diego: Singular-Thomson Learning, 2001; 233-50.

11 Madden C, Rutter M, Hilbert L, Greinwald J, Choo D. Clinical and audiological features in auditory neuropathy. Arch Otolaryngol Head Neck Surg, 2002; 128: 1026-30.

12 Rance G, Cone-Wesson B, Wunderlich J, Dowell RC. Speech perception and cortical event related potentials in children with auditory neuropathy. Ear Hear, 2002; 23: 239-53.

13 Rance G, Barker EJ. Speech and language outcome in children with auditory neuropathy/dys-synchrony managed with either cochlear implants or hearing aids. Int J Audiol, 2009; 48: 313-20.

14 Vanaja CS, Manjula P. LLR as a measure of benefit derived from hearing devices with auditory dys-synchrony. In: First Conference on Auditory Neuropathy, ed Sivashanker N, Shashikala H.R. Bangalore: Department of Speech Pathology and Audiology, National Institute of Mental Health and Neurosciences, 2004: 136-46.

15 Zeng FG, Liu S. Speech perception in individuals with auditory neuropathy. J Speech Lang Hear Res, 2006; 49: 367-80.

16 Shallop JK. Auditory neuropathy/dys-synchrony in adults and children. Semin Hear, 2002; 23: 215-22.

17 Sininger YS, Hood LJ, Starr A, Berlin CI, Picton TW. Hearing loss due to auditory neuropathy. Audiology Today, 1995; 1: 10-13.

18 Widen JE, Ferraro JA, Trouba SE. Progressive neural impairment: case report. J Am Acad Audiol, 1995; 1: 217-24.
19 Starr A. The neurology of auditory neuropathy. In: Sininger YS, Starr A (eds.), Auditory Neuropathy: A New Perspective on Hearing Disorders. San Diego: Singular-Thomson Learning, 2001; 37-48.

20 Wang Q, Gu R, Han D, Yang W. Familial auditory neuropathy. Laryngoscope, 2003; 113: 1623-29.

21 Shivashankar N, Satishchandra P, Shashikala HR, Gore M. Primary auditory neuropathy - an enigma. Acta Neurol Scand, 2003; 108: 130-35.

22 Berlin CI, Hood LJ, Morlet T, Wilensky D, St John P et al. Absent or elevated middle ear muscle reflexes in the presence of normal otoacoustic emissions: a universal finding in 136 cases of auditory neuropathy/dys-synchrony. J Am Acad Audiol, 2005; 16: 546-53.

23 Jijo PM, Yathiraj A. Audiological characteristics and duration of the disorder in individuals with auditory neuropathy spectrum disorder (ANSD) - a retrospective study. J Ind Sp Lang Hear Ass, 2012; 26: 17-26.

24 ANSI: American National Standard Institute. 1999. American national standard: Maximum permissible ambient noise for audiometric rooms. ANSI S3.1-1999. New York, ANSI.

25 Yathiraj A, Vijayalakshmi CS. Phonemically balanced wordlist in Kannada. A test developed at the department of audiology, AIISH, Mysore, 2005.

26 Young ED, Sachs MB. Representation of steady-state vowels in the temporal aspects of the discharge patterns of populations of auditory nerve fibers. J Acoust Soc Am, 1979; 66: 1381-403.

27 Bess HF, Humes LE. Amplification and rehabilitation. In Audiology: the Fundamentals, $4^{\text {th }}$ ed, Lippincott Williams \& Wilkins, 2008; 257.

28 Van Tassel DJ. Hearing loss, speech and hearing aids. J Speech Hear Res, 1993; 36: 228-44. 